\title{
DEVELOPING A MODEL OF TEACHING READING COMPREHENSION FOR EFL STUDENTS
}

\author{
Arifuddin Hamra \\ (arifhamra@unm.ac.id) \\ Eny Syatriana \\ Universitas Negeri Makassar, Indonesia
}

\begin{abstract}
This study aimed at designing a model of teaching reading comprehension based on the objectives of teaching reading at the senior high school and the teachers' understanding of the school curriculum and to describe the implementation of the model. The subject consisted of 24 teachers, 167 students of five SMAs (senior high schools) in South Sulawesi, Indonesia. This developmental study had five steps: analysis, design, development, implementation, and evaluation. The result indicates that the model significantly increases the reading comprehension of EFL students $(\underline{\mathrm{M}}=-14.43114)$, $\underline{\mathrm{t}}(166)=-16.155, \underline{\mathrm{p}}<.05$. The teachers and students stated that the learning condition, teaching and learning process, reading comprehension, instructional reading materials, and teachers' teaching performance were well established. This interactive model improved the reading comprehension of the students significantly. Thus, it is an alternative model of teaching reading for EFL students.
\end{abstract}

Key words: a model of teaching, developmental study, reading comprehension, EFL students

In Indonesia English is the first foreign language. It is used in English classrooms but not in everyday communication. This condition makes English difficult for Indonesian students. They have limited time to practice the language. A foreign language, like a native language, requires a lot of practices. In order to master a language, students should use it in every day activities, through a real practice. 
Since English in Indonesia is a foreign language, most students at any levels of education get difficulty in reading English texts. Many research results (Syatriana, 1998; Hamra, 1993 and 1996; Mardiana, 1993; Kweldju, 2001) indicated that the ability of Indonesian students to read English texts was very low. Most university graduates are not able to read English with complete comprehension. The Indonesian students need help in reading comprehension. For students, reading is a key to improve learning outcome in many fields of study. Reading is an inseparable part of any English course.

Many efforts had been carried out by the Indonesian government to improve the quality of English teachers. The qualification of English teachers were improved by facilitating them to go to university to get higher degrees, and through many other educational local activities all over the country. However, the result of the national examination for English subject was low; therefore, it still needs attention from the government and the English teachers.

Using an interactive model of teaching reading comprehension is another effort to improve the reading comprehension of EFL students, especially the Indonesian students. The research question is "How effective is the model in increasing the reading comprehension of EFL students?” This model has five general aspects: reading knowledge, reading strategy, reading skills, previous knowledge, and reading participation to help their students improve comprehension.

Learning to read refers to reading for meaning or comprehension. Reading for meaning is essentially an attempt to comprehend texts. It involves a number of metacognitive activities of comprehension monitoring. Brown (1980) presents some metacognitive activities of reading comprehension: (a) clarifying the purpose of reading, (b) identifying the important aspects of a message, (c) focusing attention on the major content, (d) monitoring ongoing activities to determine whether comprehension is occurring, (e) engaging in self-questioning to determine whether goals are being achieved, and (f) taking corrective action when failures in comprehension are detected.

In Indonesia, learning to read English starts at the fourth grade of elementary schools, and it continues at junior and senior high schools up to the higher education. Learning to read is a process that involves a number of different skills and experiences. It depends on learning to decode individual words and to comprehend the meaning of a text. The school curriculum in Indonesia states that by the end of the third grade of junior high school students are expected to recognize and understand about 1000 English words 
and about 2500 English words for senior high schools (Depdiknas, 2002). The English students at higher education are expected to read or comprehend English text books of different fields of study.

There are three important interacting factors related to learning to read: affect, cognition, and language (Kolker, 1979:4). Affective behaviors are related to feelings, cognitive behaviors to thought, and linguistic behaviors to language. Therefore, there are three assumptions that underlie these descriptions: (1) the way we feel about ourselves and our environment influences our reading achievement, (2) to understand what we read, we have to understand the concepts in the reading materials, and (3) reading is a process of interaction between the reader and the writer through written language.

Reading to learn refers to reading for remembering or studying. It involves all the activities of reading for meaning. The reading material is not only comprehensible but also memorable. Baker \& Brown (1984) mention some metacognitive aspects of reading for studying: (a) identifying important ideas, (b) testing one's mastery of materials, (c) developing effective study strategies, and (d) allocating study time appropriately. Studying which involves reading is a special form of reading in teaching and learning process. It includes some techniques that can be used in learning, among others: (a) note taking, (b) summarizing, (c) student questioning, (d) outlining, (e) networking, (f) mapping, and (g) schematizing. Networking, mapping, and schematizing are techniques for representing text diagrammatically.

There is no single definition of reading; therefore, it is difficult to formulate a perfect definition of reading. A broader definition presented by Rubin (1982:8) is that "reading is the bringing and the getting of meaning from the printed page". This definition implies that readers bring their background, experiences, and emotion into play. Consequently, upset students will bring their feelings into the act of reading, and this kind of situation will affect the reading process. Students who have more knowledge of the reading matter will get more from the material than the students who are less knowledgeable. A student who is good at critical thinking will get more than someone who is not.

Webster's New Reference Library: An Encyclopedia of Dictionary (1984) defines recognition as "an awareness that something perceived has been perceived before." Harris and Sipay (1980:366) state that "word recognition means that the reader can determine the oral equivalent of a written or printed word". If the readers are able to understand the expected meaning of a word, it means he is able to identify the word. This is called 
word identification process. Identification indicates the ability of a reader to get meaning from a word.

Many students can recognize words and know how they are pronounced, but they do not know their meanings. Harris and Sipay (1980:366) argue that "theorists differ on whether meaning can be gotten directly from written language and processed differently from spoken language, or whether written language must be encoded (translated) into spoken language before it is understood ....” The differences can be connected to the reading ability level of the reader. Skilled and unskilled readers recognize words differently. In reading comprehension, an unskilled reader may be helped by saying the words loudly.

Comprehension decodes or associates meaning with the symbols that comprise the word. Reading requires interpretation and thinking. The goal of reading is to comprehend meaning. Comprehension depends on the ability to get individual word meanings. Good readers have to learn to interpret word meanings according to the context. They have to comprehend words as parts of phrases, clauses, and sentences. Both word knowledge and vocabulary are highly related to comprehension. Comprehension deals with the relationship of meanings with word symbols, the choice of correct meaning based on the context, the organization and retention of meaning, and the ability to grasp meanings from words, phrases, sentences, or long selections. To comprehend, students need to understand syntax of the language. Dechant (1982:312) states that "comprehension is a process; it is thinking through reading". Comprehension also depends on the student's basic cognitive and intellectual skills, on the background of experience, such as vocabulary knowledge, concepts or ideas, and on language competence, such as morphology, syntax, and grammar.

Lapp \& Flood (1986) states that both word recognition and comprehension skills are necessary for readers who are encountering content area texts. Word recognition skills enable students to recognize and analyze newly encountered lexical items. Comprehension skills are needed as students recognize literal facts, infer meanings, and evaluate the writer's purpose. Most content area materials demand students to have competence in general study skills. Hildreth (1958) states that reading act has a twofold process consisting of the mechanical aspects of recognizing symbols and the mental processes of interpreting impression received. According to Lapp \& Flood (1978:6), reading process includes three processes: (1) letter and word recognition, (2) comprehension of concepts, and (3) reaction and assimilation of the new knowledge with the reader's past experience. 
Hittleman (1978:5) states that "reading is a verbal process interrelated with thinking and with all other communication abilities: listening, speaking, and writing". Harris \& Sipay (1980:8) state that "Reading is the meaningful interpretation of printed or written verbal symbols. Smith (1971:2) defines reading as "an act of communication in which information is transferred from a transmitter to a receiver ....” (p.2). Fries (1963:120) states that "the process of learning to read in one's native language is the process of transfer from the auditory signs for language signals, which the child has already learned, to the new visual signs for the same signals”.

Reading is a language process and communication that is a process which gives opportunity to readers to interact and communicate with different ideas (Dechant, 1982; Smith, 1971; Dallmann, et al., 1978). In this case, reading always involves interaction between the writer and the reader. It is an action of a communicative process starting from the thought of the writer which is expressed using symbols on printed page. Without readers communication through writing on printed page reading does not occur. Reading needs thought and creative activities. This activity requires knowledge and reading skills which are very important for readers. These skills are the skills to recognize words, to understand word meaning, to comprehend the reading material, to organize and memorize, to associate information, and to read aloud. Thus, reading requires the highest pattern of thought. Reading demands a communication to the message and comprehension at different levels, starting from the lowest level to the highest level of comprehension or from the literal comprehension to the applied reading comprehension.

This study was guided by several research questions: (1) To what extent do the teachers and students understand the school curriculum?

(2) What teaching model is suitable for reading comprehension of the senior high school students? (3) Is the teaching model effective for improving the reading comprehension of the students? (4) How is the implementation of the model in terms of the teaching and learning process?

\section{METHOD}

This developmental study consisted of several procedures: field analysis, design, prototype, formative evaluation, implementation, and summative evaluation (Gustafson, 1981). Field analysis was conducted to generate a model of teaching reading comprehension through focus group discussion to the teaching of reading comprehension, teachers and students' understanding of the school curriculum, instructional materials, and teaching me- 
thods. Teaching reading procedures and instructional materials were designed by the researcher. Formative and summative evaluations were administered during the implementation.

The subject consisted of 24 English teachers who participated in the focus group discussion (FGD): 4 teachers implemented the interactive model of teaching reading comprehension (IMTRC) in the class, and 167 students took pretest and posttest from five senior high schools in South Sulawesi province. A pretest of reading comprehension was administered to see the comprehension of the students, and a posttest to see the effectiveness of the teaching model. Questionnaires for teachers and students were administered to analyze the teaching and learning aspects: learning condition, teaching and learning process, reading comprehension, instructional reading materials, and teachers' teaching performance using the model. In the model implementation, FGD with the English teachers was conducted to discuss the teaching of reading comprehension, to detect teaching handicaps, and to find some solutions.

The IMTRC consists of five main teaching components: reading knowledge, previous knowledge, reading strategy, and reading participation of students. The teaching procedure of the model: presenting reading text, activating the previous knowledge of students through previous questions related to reading text, reading the text with reading strategies, answering comprehension questions in group, doing reading skill exercises, doing reading knowledge exercises, and thinking in English by completing exercises. The reading activities are designed in such a way to motivate students to read and to develop their reading interest and habit.

There are several other additional teaching aspects of the lesson plan and the implementation of the model: content area texts as instructional materials, teachers' participation and the strategy, class interactions and condition, group learning, individual learning, reinforcement, thinking in English, and evaluation to improve the teaching and learning process and the learning outcome.

\section{FINDINGS AND DISCUSSION}

\section{Field Analysis}

In the field analysis, the English teachers participated in the focus group discussion; to generate a teaching model. Students from different departments took part in the after class discussion; did the pretest and posttest, and answered the questionnaire (See Table 1). 
Table 1. The Number of Schools, Teachers, and Students Participating in the Study

\begin{tabular}{|c|c|c|c|c|c|c|}
\hline \multirow{2}{*}{ Schools } & \multicolumn{2}{|c|}{$\begin{array}{l}\text { The Number of } \\
\text { Participants in } \\
\text { FGD }\end{array}$} & \multirow{2}{*}{$\begin{array}{l}\text { Num- } \\
\text { bers of } \\
\text { Tests }\end{array}$} & \multicolumn{2}{|c|}{ Questionnaires } & \multirow{2}{*}{ Department } \\
\hline & $\begin{array}{l}\text { Tea- } \\
\text { chers }\end{array}$ & $\begin{array}{l}\text { Stu- } \\
\text { dents }\end{array}$ & & $\begin{array}{l}\text { Stu- } \\
\text { dents }\end{array}$ & $\begin{array}{l}\text { Tea- } \\
\text { chers }\end{array}$ & \\
\hline $\begin{array}{l}\text { SMA Negeri } 3 \text { Takalar } \\
\text { (Senior High School } 3 \\
\text { Takalar) }\end{array}$ & 5 & 4 & 31 & 31 & 5 & $\begin{array}{l}\text { Bahasa } \\
\text { (Language) }\end{array}$ \\
\hline $\begin{array}{l}\text { SMA Negeri } 3 \text { Makas- } \\
\text { sar } \\
\text { (Senior High School } 3 \\
\text { Makassar) }\end{array}$ & 6 & 6 & 40 & 39 & 6 & $\begin{array}{l}\text { IPA } \\
\text { (Natural } \\
\text { Science) }\end{array}$ \\
\hline $\begin{array}{l}\text { SMA Negeri } 16 \mathrm{Ma-} \\
\text { kassar (Senior High } \\
\text { School } 16 \text { Makassar }\end{array}$ & 3 & 6 & 38 & 38 & 3 & $\begin{array}{l}\text { IPS } \\
\text { (Social Stu- } \\
\text { dies) }\end{array}$ \\
\hline $\begin{array}{l}\text { SMA Negeri } 1 \text { Bulu- } \\
\text { kumba (Senior High } \\
\text { School } 1 \text { Bulukumba) }\end{array}$ & 6 & 5 & 29 & 29 & 6 & $\begin{array}{l}\text { IPA } \\
\text { (Natural } \\
\text { Science) }\end{array}$ \\
\hline $\begin{array}{l}\text { SMA Negeri } 3 \text { Unggu- } \\
\text { lan Palopo (Senior } \\
\text { High School } 3 \text { Palopo) }\end{array}$ & 4 & 5 & 29 & 29 & 4 & $\begin{array}{l}\text { IPS } \\
\text { (Social Stu- } \\
\text { dies) }\end{array}$ \\
\hline Total & 24 & 26 & 167 & 166 & 24 & \\
\hline
\end{tabular}

\section{Teachers' Understanding of the Curriculum}

Most English teachers (70.08\%) participated in the program of socialization on the implementation of the competency-based curriculum conducted by the government, but most of the teachers (54.16\%) did not really understand how the curriculum was to be implemented. It happened because the sets of curriculum were not in the hand of the teachers. The school curriculum was not accompanied by instructional materials and the socialization and workshop of the curriculum arranged by the government was not completely followed by all of the English teachers. Most teachers (75\%) implemented the curriculum; although they got a lot of teaching problems. They did not have complete information about the curriculum; teaching materials were not available at schools; teaching facilities were limited; students lacked in motivation; the curriculum was difficult to implement for some teachers.

Most teachers (66\%) stated that the reading materials were difficult to get for many teachers. The text types used in the teaching and learning pro- 
cess were recount, narrative, descriptive, and report. All teachers stated that language aspects, such as grammar and vocabulary helped students' comprehension. All teachers agreed that reading knowledge, previous knowledge, reading strategies, and reading participation were very essential aspects in helping comprehension. Most teachers stated that the reading comprehension of their students was poor.

\section{Students' Understanding of the Curriculum}

Almost all students (80.7\%) knew the existence of the competencybased curriculum from their teachers, the headmaster, and their reading from articles. Many students (76.92\%) got problem in understanding the curriculum because it was not available in the schools.

Almost all students (84.61\%) stated that teaching and learning process was based on the curriculum. Many of them stated that the English learning difficulties were due to the lack of teaching facilities, the insufficient knowledge of English grammar, English vocabulary, texts, reading skills, and reading strategies. Many students (73.07\%) did not know the syllabus and most students (80.76\%) did not know the lesson plan made by the teachers. Both syllabus and the lesson plan were very important in helping students' learning since they lead learning and teaching process.

All students stated that they had difficulties in reading English texts because of different reasons: (a) lack of vocabulary, (b) lack of learning support, (c) lack of language knowledge, (d) pronunciation difficulties, (e) lack knowledge of words, phrases, paragraphs, and passage or texts (f) lack of the application of reading strategies, (g) lack of reading skills and reading interest, and (h) lack of reading amount (i) lack of reading motivation.

All students stated that language elements, such as grammar and vocabulary, reading strategies, reading skills, reading amount, reading attitude, interest, and habit, reading knowledge: knowledge of words, phrases, sentences, paragraphs, or passages helped to improve their reading comprehension.

\section{The Interactive Model of Teaching Reading Comprehension}

Based on the field analysis through focus group discussion with the English teachers, the Interactive Model of Teaching Reading Comprehension (IMTRC) was designed as follows: 


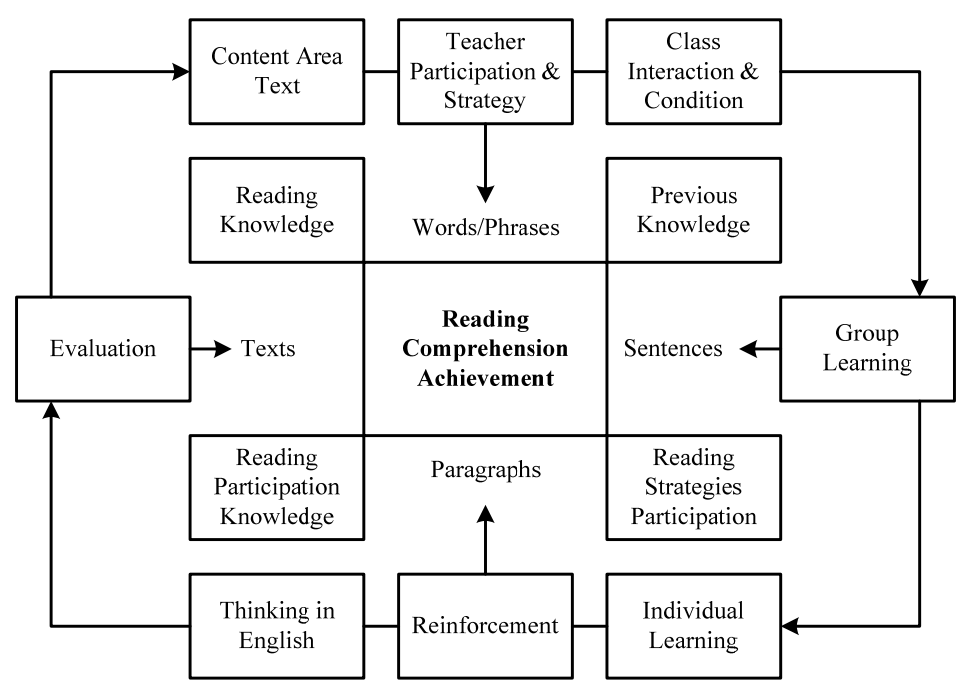

Figure 1: Interactive Model of Teaching Reading Comprehension

There are four main circles: the reading comprehension achievement as the teaching and learning objective, the reading text, the cognitive \& affective aspects, and the teaching environments in this teaching model:

1. Reading comprehension achievement is the reading achievement obtained by the students after the teaching and learning process. This is the main objective of the teaching of reading comprehension.

2. Text types, such as narrative, descriptive, explanation, etc. are constructed from sentences, paragraphs, and words/phrases.

3. a. Reading knowledge consists of knowledge of sentences, paragraphs, and words/phrases.

b. Previous knowledge is the students' knowledge that is relevant to the reading text.

c. Reading strategies involve strategies used by the students to comprehend the reading texts.

d. Reading participation refers to the frequency of reading.

4. a. Content area texts refer to the texts in the subjects taught at schools.

b. Teacher participation and strategy refer to the affective aspect of teacher in the teaching and the teaching strategies.

c. Class interaction and condition refer to the interaction in the teaching and learning process and the class arrangement.

d. Group learning requires students to work and read in groups. 
e. Individual learning requires students to work individually.

f. Reinforcement refers to the appreciation given to the students' performance.

g. Thinking in English is a reading activity to help students improve their thinking process.

h. Evaluation consists of formative and summative evaluations. Formative evaluation is administered to improve the teaching and learning process and summative evaluation measures the learning achievement of the students.

\section{Reading Achievement of the Students}

To see the effectiveness of the model, a pretest and posttest of reading comprehension were administered:

1. Result of pretest and posttest

According to the evaluation category of the senior high school, the result of the pretest was poor $(\mathrm{M}=58.23)$; the posttest result was good $(M=73.29)$. In general, there was a significant difference between the pretest and posttest $(\underline{\mathrm{M}}=-14.43113), \underline{\mathrm{t}}(166)=-16.155, \mathrm{p}<.05$, and reliability based on Cronbach's Alpha is .909. The paired sample correlation of the two tests is .838 (SPSS version 12).

The data analysis indicated that the teaching model was effective in improving the reading achievement of the students. The reading improvement is the contribution of some learning aspects, such as the reading knowledge, previous knowledge, reading strategies, and reading participation and the learning environments involved in the study: instructional materials, teacher participation and the strategies, class interaction, group learning, individual learning, reinforcement, thinking in English, and evaluation.

2. Result of pretest and posttest in five schools

The pretest and posttest were administered to see the effectiveness of the model at each school. The result indicated that there was a significant difference between the result of the pretest and posttest at each school. The detailed differences are presented in Table 2 . The teaching procedures suggested by the model were well conducted by the teachers. 
Table 2. The Result of Pretest and Posttest

\begin{tabular}{|c|c|c|c|c|c|c|c|c|}
\hline \multirow{3}{*}{ 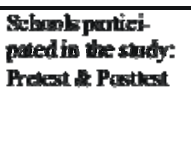 } & \multicolumn{5}{|c|}{ Pained Differenoes } & \multirow{3}{*}{$\mathbf{T}$} & \multirow{3}{*}{ Df } & \multirow{3}{*}{$\begin{array}{l}\text { sig } \\
\text { (2 } \\
\text { teiledi) }\end{array}$} \\
\hline & \multirow[t]{2}{*}{ Mem } & \multirow{2}{*}{$\begin{array}{l}\text { Standand } \\
\text { Devintion }\end{array}$} & \multirow[t]{2}{*}{$\begin{array}{l}\text { Std } \\
\text { Ertor } \\
\text { Mean }\end{array}$} & \multicolumn{2}{|c|}{ 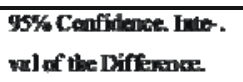 } & & & \\
\hline & & & & Lewart & Uppar & & & \\
\hline Pair 1 sina 3 thk & -1032258 & 12.7599 & 225463 & -15.02055 & -569631 & -4499 & 30 & .000 \\
\hline Pair $2 \mathrm{sma} 3 \mathrm{mks}$ & -1250000 & 7.76050 & 122736 & -14.98257 & -1001743 & -10.184 & 39 & .000 \\
\hline Pair 3 sma $16 \mathrm{r}^{2}$ s. & -2000000 & 9.29981 & 150563 & -23.05677 & -1694323 & -13257 & 37 & .000 \\
\hline Pair 4 ona 1 bll & -931034 & 8.83602 & I. G4055 & -126746 & -5.94923 & -5.674 & $2 \mathrm{z}$ & .000 \\
\hline Pair 5 smapts & -1931034 & 34.86991 & 2.76016 & -24.9428 & -13.65641 & -6996 & 28 & .000 \\
\hline
\end{tabular}

\section{The Implementation of Teaching and Learning Process}

The questionnaire for the teaching and learning process was analyzed quantitatively. The students stated that the teaching and learning process of the implemented model was good $(\underline{M}=72.0422)$. The teachers stated that the teaching and learning process presented by the model was good $(\underline{\mathrm{M}}=81.8333)$.

Teachers and students evaluated the five learning aspects: (1) the learning condition, (2) the teaching and learning process, (3) the reading comprehension, (4) instructional reading materials focused on content area texts, and (5) the teachers' teaching performance improved the reading comprehension of the students. The teachers' evaluation was better than the students'. The mean of each learning aspect is presented in Table 3.

Table 3. The Mean of Teaching and Learning Aspects

\begin{tabular}{|c|c|c|}
\hline $\begin{array}{l}\text { Teaching and Learning As- } \\
\text { pects }\end{array}$ & $\begin{array}{c}\text { Mean of Teachers' Ques- } \\
\text { tionnaire }\end{array}$ & $\begin{array}{l}\text { Mean of Students' Ques- } \\
\text { tionnaire }\end{array}$ \\
\hline 1. Learning condition & 82.08 & 70.69 \\
\hline $\begin{array}{l}\text { 2. Teaching \& learning } \\
\text { process }\end{array}$ & 83.54 & 73.54 \\
\hline $\begin{array}{l}\text { 3. Reading comprehen- } \\
\text { sion }\end{array}$ & 79.83 & 72.73 \\
\hline $\begin{array}{l}\text { 4. Instructional reading } \\
\text { materials) }\end{array}$ & 79.46 & 67.44 \\
\hline $\begin{array}{l}\text { 5. Teachers' teaching } \\
\text { performance }\end{array}$ & 80.00 & 74.79 \\
\hline
\end{tabular}




\section{CONCLUSIONS AND SUGGESTIONS}

Most teachers did not comprehend and implement completely the school curriculum in their teaching. Some of them had difficulties in designing lesson plans and evaluating the learning outcome because teaching and learning facilities, books, language laboratory, and teaching media were not available at the schools.

The Interactive Model of Teaching Reading Comprehension (IMTRC) which consists of learning aspects: previous knowledge, reading skills, reading knowledge, and reading participation as well as learning environments: the instructional reading materials, teacher participation and strategy, class interaction and condition, group learning, individual learning, reinforcement, thinking in English, and evaluation is suitable for reading comprehension improvement

The IMTRC is very effective in improving the reading comprehension of the students. The implementation of the teaching model is accepted by the teachers and students. It is good in relation to the improvement of teaching and learning process.

The IMTRC is best implemented to EFL students in order to improve their reading comprehension. In using this model teachers should consider and control some supporting learning aspects: reading knowledge, previous knowledge, reading strategies, and reading participation as well as teaching environments: the instructional reading materials, teacher participation and strategy, class interaction and condition, group learning, individual learning, reinforcement, thinking in English, and evaluation.

Reading is a skill that needs exercises. The exercises should consider the reading knowledge, prior knowledge, reading strategies, and reading participation. The learning and teaching process should be designed in such a way to increase the reading motivation and interest of the students. Using content area or subject texts helps students to recognize the language of the subjects they study at schools.

The IMTRC is an alternative model that can be used to improve the reading comprehension of EFL students. Good readers should be the main objective of the English teachers at each school. The students should increase the amount of reading because it will determine the number and quality of the global knowledge. 
Hamra \& Syatriana, Developing a Model of Teaching Reading 39

\section{REFERENCES}

Baker, L. \& Brown, A. L. 1984. Metacognitive Skills and Reading. In Pearson, P.D. (Ed.), Handbook of Reading Research (pp. 353-394). New York: Longman.

Brown, A. L. 1980. Metacognitive Development and Reading. In Spiro, R. J. Bruce, B. C. \& Brewer, W. F. (Eds.), Theoretical Issues in Reading Comprehension. Hilsdale, New Jersey: Erlbaum.

Dallmann, M., Rouch, R. L., Char, L. Y. C., \& DeBoer, J. J. 1978. The Teaching of Reading. NY: Holt, Rinehart \& Winston.

Dechant, E. V. 1982. Improving the Teaching of Reading. New Jersey: Prentice-Hall.

Depdiknas. 2002. Kurikulum Berbasis Kompetensi (Competency-Based Curriculum). Jakarta: Pusat Kurikulum, Balitbang Depdiknas.

Fries, C. C. 1963. Linguistics and Reading. New York: Holt, Rinehart \& Winston.

Gustafson, K.L. 1981. Survey of Instructional Development Models. ERIC Clearinghouse on Information Resources. New York: Syracuse University.

Hamra, A. 1993. Advancing Child Language Development. Jurnal Pendidikan dan Keguruan. XVIII (3): 167-171

Hamra, A. 1996. Developing Questioning Competencies through Radio Reading. Jurnal Jaringan. 1 (3): 199-195.

Harris , R. A. \& Sipay, E. R. 1980. How to Increase Reading Ability. NY: David McKay.

Hildreth, G. 1958. Teaching Reading. New York: Holt, Rinehart \& Winston.

Hittleman, D. R. 1978. Developmental Reading: A Psycholinguistic Perspective. Chicago: Rand McNally College Publishing Company.

Kolker, B. 1979. Processing Print. In Alexander, J.E. (Ed.), Teaching Reading (pp.4-25). Boston: Little, Brown and Company.

Kweldju, S. 2001. Vocabulary and Lexicogrammatical Units: Graduate Students' Main Problem in Reading Their Textbooks. Linguistik Indonesia. Jurnal Ilmiah Masyarakat Linguistik Indonesia. 1: 35-56. 
Lapp, D., \& Flood, J. 1986. Teaching Student to Read. NY: Macmillan Publishing Company.

Mardiana. 1993. The Correlation Between the Reading Comprehension Achievement of the Fifth Semester Students of the English Department of FPBS IKIP Ujung Pandang and Their Attitude towards English. Unpublished Sarjana Thesis. Ujung Pandang: FPBS IKIP.

Rubin, D. 1982. Diagnosis and Correction in Reading Instruction. New York: Holt, Rinehart \& Winston.

Syatriana, E. 1998. The Levels of Reading Comprehension of the Fifth Semester students of STKIP YPUP Ujung Pandang. Unpublished Sarjana Thesis, Ujung Pandang, STKIP YPUP.

Smith, F. 1971. Understanding Reading: A Linguistic Analysis of Reading and Learning to Read. New York: Holt, Rinehart and Winston.

SPSS, 12. (2004). Pengolahan Data Statistik dengan SPSS 12 (Statistical Data Analysis with SPSS 12). Semarang: Penerbit Andi and Wahana Komputer.

Webster's New Reference Library: An Encyclopedia of Dictionaries. (1984). Cambridge, Ontario: Thomas Nelson Publishers. 